American Journal of Agricultural and Biological Sciences 4 (4): 311-318, 2009

ISSN 1557-4989

(C) 2009 Science Publications

\title{
Physiological Response of Soybean (Glycine max) to Foliar Application of Methanol Under Different Soil Moistures
}

\author{
${ }^{1}$ Farzad Paknejad, ${ }^{2}$ Mojtaba Mirakhori, ${ }^{3}$ Majid Jami Al-Ahmadi, ${ }^{4}$ Mohammad Reza Tookalo, ${ }^{5}$ Ali Reza \\ Pazoki and ${ }^{2}$ Parisa Nazeri \\ ${ }^{1}$ Department of Agronomy and Plant Breeding, Islamic Azad University, Karaj Branch-Iran \\ ${ }^{2}$ Islamic Azad University, Karaj Branch, Member of Young Researcher Club \\ ${ }^{3}$ Department of Agronomy and Plant Breeding, Faculty of Agriculture, the University of Birjand, Iran \\ ${ }^{4}$ Department of Agronomy, Faculty of Agriculture, Islamic Azad University, Bojnord Branch- Iran \\ ${ }^{5}$ Department of Agronomy, Faculty of Agriculture, Islamic Azad University, Shahr_e _Rey Branch-Iran
}

\begin{abstract}
Problem statement: Many cultivated area are situated in arid zone, where crop photosynthesis and productivity has limited by drought. Thus any treatment, such as methanol, that improve plant water relation and reduce stress impacts, could be benefit. Approach: In order to investigate effects of methanol application on some physiological properties of soybean under low water stress, a factorial experiment was done at Research Field of Faculty of Agriculture and Natural Resources, Islamic Azad University-Karaj Branch, Karaj, Iran, during 2008, based on a randomized complete block design with three replications. The first factor was different levels of methanol equal to 0 (control), 7, 14, 21, 28 and 35 volumetric percentage (v/v), which were used as foliar applications at three times during growth season of soybean, with 15 days intervals. The second factor was water stress conditions in two levels, based on depletion of 40 and $70 \%$ of available soil moisture. Some traits such as Grain Yield, Relative Water Content (RWC), chlorophyll fluorescence parameters and chlorophyll content were measured, one day before and after the third methanol application. Results: Chlorophyll content (Chl), GY, Electrolytes Leakage at second sampling, photochemical capacity of PSII $\left(\mathrm{F}_{\mathrm{v}} / \mathrm{F}_{\mathrm{m}}\right)$, maximum and variable fluorescence $\left(\mathrm{F}_{\mathrm{m}}\right.$ and $\mathrm{F}_{\mathrm{v}}$, respectively) were affected by water stress significantly $(\mathrm{p}<0.05)$. As drought severity was increased, mean values of photochemical capacity of PSII, Chl and RWC tend to decline, whereas minimum fluorescence $\left(\mathrm{F}_{0}\right)$ and Electrolytes Leakage were increased. Methanol foliar application influenced significantly $(p<0.05)$ Chl, RWC, Grain Yield, and all fluorescence parameters. There was a positive, high correlation between GY with maximum fluorescence, photochemical capacity and also Chl and RWC in both samplings. Conclusion: It seems applying methanol on water stressed soybean plants can reduce harmful effects of drought and improve plant potential to cope with stress.
\end{abstract}

Key words: Chlorophyll content, chlorophyll fluorescence, drought stress, grain yield, relative water content

\section{INTRODUCTION}

In General, drought is one of the most important limiting factors of crop yields in arid zones. The reduction of photosynthesis under drought stress is appeared to be associated with disturbance in biochemical reactions ${ }^{[9]}$. Photosystem II (PSII) is highly sensitive to environmental inhibiting factors and water stress will damage its reaction centers severely. The chemical reaction of PSII is also affected strictly by water stress ${ }^{[18]}$. When stomata are closed due to drought or high temperature, the available $\mathrm{CO}_{2}$ in intercellular space $\left(\mathrm{C}_{\mathrm{i}}\right)$ would be reduced, leading to reduced electron transport capacity and restricted assimilation potential ${ }^{[16]}$. On the other hand, stomata closure will result in evaluated temperatures of leaf and plant, limiting light reaction of photosynthesis ${ }^{[3]}$.

The study of chlorophyll fluorescence parameters is a simple, non-destructive method, rapidly lead to valuable results. One can detect the imbalance between two metabolic and anabolic processes, which are affected by heat and drought stress, by using chlorophyll fluorescence technique ${ }^{[10]}$. The chlorophyll fluorescent measurements in field can reflect the exact

Corresponding Author: Majid Jami Al-Ahmadi, Faculty of Agriculture, the University of Birjand, P.O.Box 97175-331, Birjand, Iran Tel: +98 561 2254041/ +98 9155098836 Fax: +98 5612254050 
response of photosynthetic apparatus which is more restricted under natural conditions ${ }^{[3]}$. One of the most important parameters in rapid fluorescence kinetics is variable Fluorescence $\left(F_{v}\right)$, i.e., the difference between maximal and minimal fluorescence $\left(\mathrm{F}_{\mathrm{m}}-\mathrm{F}_{0}\right)$. The variable to maximum fluorescence ratio $\left(\mathrm{F}_{\mathrm{v}} / \mathrm{F}_{\mathrm{m}}\right)$ is an indicative of potential or maximum quantum yield of PS II ${ }^{[4]}$. The declining slope of $F_{v} / F_{m}$ is a good indicator to evaluate photoinhibition of plants exposed to environmental stresses such as drought and heat, accompanied by high irradiance ${ }^{[3,12]}$. According to Paknejad et al. ${ }^{[24,25]}$, drought stress reduces the variable $\left(\mathrm{F}_{\mathrm{v}}\right)$ and initial $\left(\mathrm{F}_{0}\right)$ fluorescence parameters and quantum yield $\left(\mathrm{F}_{\mathrm{v}} / \mathrm{F}_{\mathrm{m}}\right)$.

Commonly, the chlorophyll fluorescence measurement technique is used simultaneously with measuring chlorophyll content, Relative Water Content (RWC) and electrolytes leakage (as a measure of membrane stability), which all are indices of plant drought resistance ${ }^{[21]}$. The photosynthesis permanence and maintenance of chlorophyll concentrations under stress conditions can be considered among other physiological indices of drought tolerance. Total chlorophyll concentration is reduced under drought stress ${ }^{[12]}$, with more retention of chlorophyll content under drought, more stability in photosynthesis ${ }^{[6]}$. The reduction in chlorophyll content by water stress seems to be a consequence of Reactive Oxygen Species (ROS), leading to chlorophyll proxidation and thereby its break-down ${ }^{[6]}$.

More recently, scientists are seeking to find compounds to be used in field, to raise plant internal $\mathrm{CO}_{2}$ concentration and to stabilize their yield. Many Researches have done in recent years on using some compounds such as methanol, ethanol, bothanol, propanol and some amino acids like as glycine, aspartat and glutamate, to improve yields of, especially, $\mathrm{C}_{3}$ crops $^{[22]}$. In general, these compounds play primarily a role in preventing increasing photorespiration induced in stressed plants ${ }^{[28]}$. It is important, because $25 \%$ of total plant carbon gain is using in photorespiration ${ }^{[7]}$.

It was first reported at the early 90s that foliar application of methanol solutions on crops will improve their yields, accelerate ripening, reduce impacts of drought and decline crop water requirements ${ }^{[22,27]}$. Applying a $20 \%$ volumetric solution of methanol on peanut (Arachis hypogaea) plants increased LAI, CGR, RUE, protein content and grain yield ${ }^{[30]}$. This increased yield has resulted from a reduced photorespiration along with an increased cell turgor of plant's tissues and from an enhanced photosynthesis capacity during reproductive stage due to an increased $\mathrm{C}_{\mathrm{i}}^{[22]}$. Methanol application also can enhance plant photosynthetic capacity by delaying leaves senescence and therefore extending photosynthesis active course ${ }^{[11]}$ and by increasing activity of FBPase, an important enzyme controlling photosynthesis ${ }^{[2]}$.

It seems met anole can act as an alternative source of carbon especially for $\mathrm{C}_{3}$ plants, causing a substantial increase in their $\mathrm{CO}_{2}$ fixation, growth and yield ${ }^{[30]}$, primarily due to inhibiting their photorespiration. The reason for this is rapid uptake of methanol by plants and its quick metabolizing to $\mathrm{CO}_{2}$ in plant tissues ${ }^{[8]}$, as a result of smaller size of methanol molecules compared to $\mathrm{CO}_{2}$. The main source of methanol generation in plants is demethylation of their cellular pectin. This volatile compound escapes through leaf stomata ${ }^{[8]}$ and it may certainly be stated that plant tissues metabolize methanol. The ${ }^{14} \mathrm{C}$ labeled methanol rapidly enters tissues after foliar application and, after influencing plant carbon metabolism, can be found in serine structure $^{[8]}$. Increased methanol concentration in plant tissues has a positive effect on carbon conversion efficiency $^{[11,29]}$ and can increase leaves expansion by stimulating genes encoding for pectin methyl esterase, which enhance plant's access to $\mathrm{Ca}$ in order to increasing leaf area ${ }^{[29]}$. Furthermore, there are some symbiotic bacteria, called methylotrophic bacterium, living on leaves of most plant. These bacterium catch escaped methanol from leaves and as a trade-off, supply plants with substrate to form some phytohormons such as auxins and cytokines. In addition, these bacteria may involve in nitrogen metabolism in plants, by releasing bacteria urea, enhancing $\mathrm{N}$ assimilation in methanol sprayed plants $^{[7]}$.

It has been shown that foliar application of methanol on some crops caused an increase of chlorophyll concentration in their leaves ${ }^{[27,29]}$, whereas Li et $a l .^{[15]}$ observed any obvious changes in chlorophyll contents of soybean leaves; however, grain yield, grain weight and pods per plant was increased significantly in methanol treated plants compared to control, with the highest effects with $25 \%$ (v/v) methanol solutions. Some studies on positive effects of methanol foliar application on plant growth and yield have declared that applying methanol on water-deficit plants has increased their chlorophyll concentrations and biomass, whereas treating well-watered crops with methanol has reduced their chlorophyll content and biomass accumulation ${ }^{[22,28,30,36]}$.

There is also a positive correlation between RWC, leaf chlorophyll concentration and rubisco activity ${ }^{[6]}$, which involved $50 \%$ of soluble proteins in leaves (16). It has been shown that initial weight of plant leaves reduce under drought stress and, to reach to full turgor, these leaves should absorb more water and thereby have 
a higher fresh weight increase (22). On the other hand, as leaf RWC decrease, both photosynthesis light saturation and quantum yield will reduce $^{[31]}$ and, as Makhdum et al. ${ }^{[17]}$ have reported, treating stressed plants with methanol $(15 \%)$ can improve their turgor. This is important because desiccation can destroy cell wall, leading to leakage of cytoplasmic contents that reflect membrane injury and can be measured as a drought tolerance index ${ }^{[27]}$.

Form above, it can be concluded that applying methanol is probably a useful approach to enhance plant capacity to cope with water shortage during its growth period. Thus, this study was aimed to investigate response of soybean plants to foliar application of methanol under drought stress, using chlorophyll fluorescence parameters and some other physiological indices, such as chlorophyll concentration, RWC, cytoplasmic membrane stability and grain yield.

\section{MATERIALS AND METHODS}

This study was conducted during 2008 in Research Field of Islamic Azad University-Karaj Branch, Mahdasht, Karaj, Iran $\left(35^{\circ} 45^{\prime} \mathrm{N}, 51^{\circ} 06^{\prime} \mathrm{E}, 1313 \mathrm{~m}\right)$. The location has a semi-arid climate with $275 \mathrm{~mm}$ annual precipitation in average. The soil was clay loam with a $\mathrm{pH}$ of 7.6 and its salinity in $0-30 \mathrm{~cm}$ of soil profile was $5.55 \mathrm{dS} \mathrm{m}^{-1}$. A factorial experiment was used based on completely randomized block design with three replications. The first factor was consisted of six levels, including no methanol (M0; control) and foliar application of methanol using solutions of 7, 14, 21, 28 and 35 volumetric percentage (v/v; M1 to M5, respectively). The irrigation amount, as second factor, was imposed with irrigating after depleting 70 (T1, stress) and 40 (T2, normal) percent of available moisture. Each plot consisted of six rows, $60 \mathrm{~cm}$ spaced, which plants distance in row was considered about $10 \mathrm{~cm}$. Before planting, $23 \mathrm{~kg} \mathrm{P}_{2} \mathrm{O}_{5} \mathrm{ha}^{-1}$ and $27 \mathrm{~kg} \mathrm{~N} \mathrm{ha}^{-1}$ was used, based on soil analysis (0$30 \mathrm{~cm}$ ). In 4 May 2008, disinfected soybean seeds were sown in a depth of $5 \mathrm{~cm}$.

To exert exact water treatments, some gypsum blocks, already calibrated, were installed in plots. Concerning the calibration curve of these gypsum blocks, which was determined previously (Fig. 1) ${ }^{[25]}$, irrigations were done when needed by monitoring soil moisture during growth season. Rill irrigation technique was used and all treatments well-watered until the fifth or sixth leaves were appeared (V5-V6 stages). Two rows $(120 \mathrm{~cm})$ were left non-planted between each two adjacent plots to avoid from interference among watering treatments.

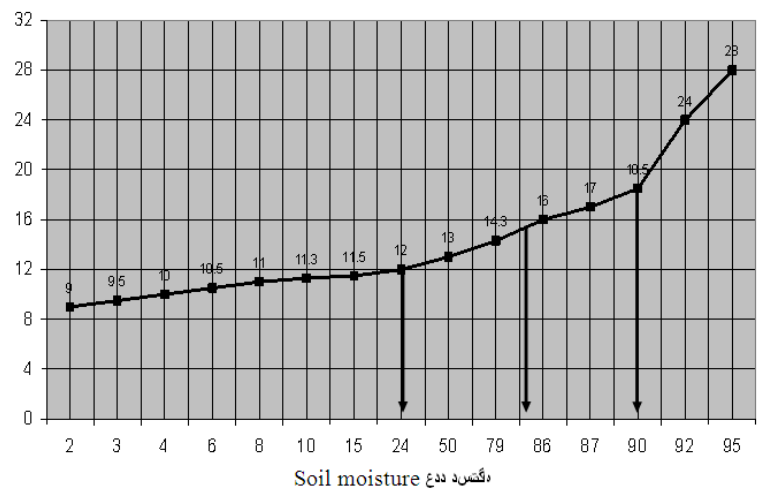

Fig. 1: Soil moisture curve and changes of electrical conductivity of gypsum blocks ${ }^{[25]}$

Plants were sprayed with methanol solutions three times during growth season, in 15 days intervals, starting from 60 days after sowing (60 DAS; 16 July). The measurements of chlorophyll fluorescence were done $24 \mathrm{~h}$ before and after the third methanol applications, from 10:30 am to $13: 30 \mathrm{pm}$, using a portable fluorescence analyzer (Pam 2000, Waltz, Germany) on the third and fourth upper leaves. After starting, the leaf was illuminated by a modulated light at $695 \mathrm{~nm}$ and then fluorescence parameters such as initial $\left(\mathrm{F}_{0}\right)$, maximum $\left(\mathrm{F}_{\mathrm{m}}\right)$ and variable $\left(\mathrm{F}_{\mathrm{v}}\right)$ fluorescence and also yield potential $\left(\mathrm{F}_{\mathrm{v}} / \mathrm{F}_{\mathrm{m}}\right)$, Quantum Yield (QY), photochemical and non-photochemical quenching of chlorophyll fluorescence ( $\mathrm{qP}$ and $\mathrm{qN}$, respectively), maximum fluorescence in a pulse of saturating light $\left(\mathrm{F}_{\mathrm{m}}{ }^{\prime}\right)$ and $\mathrm{F}_{\mathrm{t}}$ were recorded. Irradiation level (PFD: Photon Flux Density) was $400 \mu \mathrm{mol}$ photon $\mathrm{m}^{-2} \mathrm{sec}^{-1}$, with an illuminating time of $5 \mathrm{sec}$, for all treatments.

To determine leaf chlorophyll concentration, their SPAD values was determined with a portable device (SPAD-502, Minolta) in all treatments. Then some leaf sample was taken randomly and after transferring samples to laboratory and getting their extracts ${ }^{[25]}$ (Paknejad, and Nasri, 2007), the chlorophyll content readings were taken using a spectrophotometer at 647 and $663 \mathrm{~nm}$ wavelengths. Then, chlorophyll content was calculated as follow:

$\mathrm{Chla}+\mathrm{b}=\left(7.15 \times \mathrm{A}_{663}\right)-\left(18.71 \times \mathrm{A}_{647}\right) \times \mathrm{D}$

in which $\mathrm{Chl} \mathrm{a}+\mathrm{b}$ is sum of $\mathrm{Chl} \mathrm{a}$ and $\mathrm{Chl} \mathrm{b}$; $\mathrm{A}$ is light absorbance by extracts at corresponding wavelengths; $\mathrm{D}$ indicate outer thickness of cuvette $(\mathrm{cm})$. The values then converted to a surface area basis: 


$$
\mathrm{PC}=\left(\frac{\mathrm{V}}{1000} \times \frac{1}{\mathrm{~A}}\right) \times \mathrm{Chl}
$$

Where:

$\mathrm{PC}=$ Total leaf chlorophyll concentration $\left(\mathrm{mg} \mathrm{m}^{-2}\right)$

A = Used leaf surface area $\left(\mathrm{m}^{2}\right)$

$\mathrm{V}=$ The used $80 \%$ acetone $(\mathrm{L})$

$\mathrm{Chl}=$ Chlorophyll contents determined from pervious equations as $\mathrm{mg} \mathrm{L}^{-1}$

After measuring $\mathrm{Chl} a+b$ of samples and concerning their associated SPAD readings already taken in field for all treatments, a linear regression was fitted between them. The equation for sampling before the third methanol application was $\mathrm{Y}=8.345 \mathrm{x}+31.075$ $\left(\mathrm{r}^{2}=0.951\right)$ and for after application was $\mathrm{Y}=7.479 \mathrm{x}+51.6\left(\mathrm{r}^{2}=0.959\right)$, in which $\mathrm{Y}$ and $\mathrm{X}$ refer to chlorophyll concentration $\left(\mathrm{mg} \mathrm{m}^{-2}\right)$ and SPAD readings, respectively.

Leaves Relative Water Content (RWC) was determined with methods described by Matin et al. ${ }^{[19]}$, as:

$\operatorname{RWC}(\%)=\frac{\mathrm{F}_{\mathrm{w}}-\mathrm{D}_{\mathrm{w}}}{\mathrm{T}_{\mathrm{w}}-\mathrm{D}_{\mathrm{w}}} \times 100$

where, $F_{w}, D_{w}$ and $T_{w}$ are fresh, dry and turgor leaf weights, respectively.

SPAD readings and measurements of chlorophyll content and RWC were taken two times, $24 \mathrm{~h}$ before and after the third methanol applications. Analysis of variance and all other statistics were done using SAS. Mean comparisons was done by the Least Significant Difference (LSD) procedure at 0.05 probability level.

\section{RESULTS}

Effects of soil moisture: Soil moisture level had any effect on Relative Water Content (RWC) and Chlorophyll content ( $\mathrm{Chl} \mathrm{ab}$ ) measured before the third methanol application, whereas both parameters were influenced significantly after the third methanol application (Sampling 2, p<0.05). Soil moisture also had a significant effect on grain yield at 0.01 probability level (Table 1).

Irrigation treatments were started from early soybean growth stage (V6: Six trefoil leaves). When irrigating at $40 \%$ Soil Moisture Depletion (SMD) (normal condition), plants tend to produce $16.4 \%$ more grain yield, compared with plants irrigated at $70 \%$ SMD (stress condition; Table 2). Chlorophyll content also showed a remarkable reduction under irrigation at $70 \%$ SMD (Table 2).

At the second sampling, leaf RWC was significantly lower in plants irrigated at $70 \%$ SMD (Table 2).

Irrigation level affected photochemical capacity of PSII $\left(\mathrm{F}_{\mathrm{v}} / \mathrm{F}_{\mathrm{m}}\right)$, at 0.05 and parameters of variable $\left(\mathrm{F}_{\mathrm{v}}\right)$ and maximum $\left(\mathrm{F}_{\mathrm{m}}\right)$ fluorescence at 0.01 probability levels (Table 3), whereas initial Fluorescence $\left(\mathrm{F}_{0}\right)$, Quantum Yield (QY), photochemical and nonphotochemical quenching ( $\mathrm{qP}$ and $\mathrm{qN}$, respectively) and the maximum illuminated fluorescence (Fm') were not affected by irrigation (Table 3 ). Still, the $\mathrm{F}_{0}$ was slightly higher with plants irrigated at 70\% SMD (Table 4).

The higher values of $F_{m}, F_{v}$ and $F_{v} / F_{m}$ parameters were observed with irrigation at $40 \%$ SMD (control), with $13.3 \%$ lower $F_{v}$ value in stress condition $(70 \%$ SMD) than control (Table 4). There was also a $13.6 \%$ lower $\mathrm{F}_{\mathrm{v}} / \mathrm{F}_{\mathrm{m}}$ value in stress than normal conditions (Table 4).

Table 1: Mean squares of grain yield, Relative Water Content (RWC) and chlorophyll concentration ( $\mathrm{Chl} \mathrm{ab}$ ) of soybean plants in two separate samplings at $24 \mathrm{~h}$ before and after the third methanol foliar application, as affected by soil moisture and methanol application

\begin{tabular}{|c|c|c|c|c|c|}
\hline \multirow[b]{3}{*}{ Source of variance } & \multicolumn{5}{|c|}{ Mean squares } \\
\hline & \multirow[b]{2}{*}{ GY } & \multicolumn{2}{|c|}{ Before methanol } & \multicolumn{2}{|c|}{ After methanol } \\
\hline & & RWC & Chl.ab & RWC & Chl.ab \\
\hline Replication & $3602.2^{\text {ns }}$ & $24.60^{\mathrm{ns}}$ & $80.0^{\text {ns }}$ & $23.29^{\mathrm{ns}}$ & $42.8^{\text {ns }}$ \\
\hline Soil moisture (S) & $503863.0 * *$ & $29.90^{\mathrm{ns}}$ & $240.0^{\mathrm{ns}}$ & $116.80^{*}$ & $1595.0 *$ \\
\hline Methanol (M) & $155146.6^{*}$ & $67.60^{\mathrm{ns}}$ & $315.0^{\mathrm{ns}}$ & $105.10^{*}$ & $3554.0 * *$ \\
\hline $\mathrm{S} \times \mathrm{M}$ & $35245.3^{\mathrm{ns}}$ & $5.90^{\mathrm{ns}}$ & $164.0^{\mathrm{ns}}$ & $9.71^{\mathrm{ns}}$ & $583.2^{\text {ns }}$ \\
\hline Error & 37767.1 & 35.91 & 415.0 & 38.67 & 392.0 \\
\hline $\mathrm{CV}$ & 12.2 & 12.10 & 9.6 & 12.07 & 9.5 \\
\hline
\end{tabular}

Table 2: Means grain yield and leaf Relative Water Content (RWC) and chlorophyll content in different soil moistures and various concentration of methanol

\begin{tabular}{|c|c|c|c|c|c|}
\hline \multirow[b]{2}{*}{ Treatment } & \multirow[b]{2}{*}{$\begin{array}{l}\text { GY } \\
\left(\mathrm{kg} \mathrm{ha}^{-1}\right)\end{array}$} & \multicolumn{2}{|c|}{ Before methanol } & \multicolumn{2}{|c|}{ After methanol } \\
\hline & & $\begin{array}{l}\text { RWC } \\
(\%)\end{array}$ & $\begin{array}{l}\mathrm{Chl} \mathrm{ab} \\
\left(\mathrm{mg} \mathrm{m}^{-2}\right)\end{array}$ & $\begin{array}{l}\text { RWC } \\
(\%)\end{array}$ & $\begin{array}{l}\text { Chl ab } 2 \\
\left(\mathrm{mg} \mathrm{m}^{-2}\right)\end{array}$ \\
\hline \multicolumn{6}{|l|}{ Soil moisture } \\
\hline $40 \%$ (normal) & 14675.59 & 50.39 & 213.9 & 53.28 & 215.00 \\
\hline $70 \%$ (stress) & 1438.98 & 48.50 & 208.7 & 49.68 & 201.00 \\
\hline \multicolumn{6}{|l|}{ Methanol (v/v) } \\
\hline 0 (control) & 1436.0 & 46.17 & 206.00 & 48.1 & 197.87 \\
\hline $7 \%$ & 1609.0 & 52.50 & 214.00 & 54.5 & 204.92 \\
\hline $14 \%$ & 1623.9 & 52.50 & 217.00 & 55.2 & 245.90 \\
\hline $21 \%$ & 1811.0 & 52.30 & 220.00 & 55.9 & 229.35 \\
\hline $27 \%$ & 1517.1 & 47.50 & 201.00 & 47.5 & 188.90 \\
\hline $35 \%$ & 1352.1 & 45.70 & 207.00 & 47.3 & 184.34 \\
\hline $\mathrm{LSD}_{0.05}$ & 231.6 & 7.17 & 24.39 & 7.4 & 23.71 \\
\hline
\end{tabular}


Am. J. Agri. \& Biol. Sci., 4 (4): 311-318, 2009

Table 3: Mean squares of chlorophyll fluorescence parameters of soybean plants as affected by soil moisture and methanol application

\begin{tabular}{|c|c|c|c|c|c|c|c|c|}
\hline \multirow[b]{2}{*}{ Source of variance } & \multicolumn{8}{|c|}{ Mean squares } \\
\hline & $\mathrm{F}_{0}$ & $\mathrm{~F}_{\mathrm{m}}$ & $F_{v}$ & $\mathrm{~F}_{\mathrm{v}} / \mathrm{F}_{\mathrm{m}}$ & QY & $\mathrm{qP}$ & $\mathrm{qN}$ & $\mathrm{F}_{\mathrm{m}}{ }^{\prime}$ \\
\hline Replication & $1041.80^{\text {ns }}$ & $41694.0^{\mathrm{ns}}$ & $43518.00^{\mathrm{ns}}$ & $0.008^{\text {ns }}$ & $0.0010^{\text {ns }}$ & $0.0020^{\mathrm{ns}}$ & $0.007^{\mathrm{ns}}$ & $142360.00^{\text {ns }}$ \\
\hline Stress (S) & $36.00^{\mathrm{ns}}$ & $5490.0 * *$ & $558009.00 * *$ & $0.110 *$ & $0.0002^{\mathrm{ns}}$ & $0.0011^{\mathrm{ns}}$ & $0.070^{\mathrm{ns}}$ & $146816.00^{\mathrm{ns}}$ \\
\hline Methanol (M) & $4928.00^{\mathrm{ns}}$ & $113903.0^{*}$ & $117964.00 *$ & $0.030 *$ & $0.0022^{\mathrm{ns}}$ & $0.0011^{\mathrm{ns}}$ & $0.800^{\mathrm{ns}}$ & $26902.00^{\mathrm{ns}}$ \\
\hline $\mathrm{S} \times \mathrm{M}$ & $1493.00^{\mathrm{ns}}$ & $19339.0^{\mathrm{ns}}$ & $29261.00^{\mathrm{ns}}$ & $0.009^{\mathrm{ns}}$ & $0.0020^{\mathrm{ns}}$ & $0.0004^{\mathrm{ns}}$ & $0.020^{\mathrm{ns}}$ & $11979.00^{\mathrm{ns}}$ \\
\hline Error & 2153.20 & 39505.0 & 41322.00 & 0.012 & 0.0020 & 0.0010 & 0.044 & 65381.00 \\
\hline $\mathrm{CV}$ & 10.83 & 9.9 & 13.02 & 14.800 & 7.6000 & 4.3000 & 18.700 & 13.79 \\
\hline
\end{tabular}

Table 4: Means values of chlorophyll fluorescence parameters under different soil moistures and various concentration of methanol Chlorophyll fluorescence parameters

\begin{tabular}{|c|c|c|c|c|c|c|c|c|}
\hline Treatment & $\mathrm{F}_{0}$ & $\mathrm{~F}_{\mathrm{m}}$ & $\mathrm{F}_{\mathrm{v}}$ & $\mathrm{F}_{\mathrm{v}} / \mathrm{F}_{\mathrm{m}}$ & QY & $\mathrm{qP}$ & $\mathrm{qN}$ & $\mathrm{F}_{\mathrm{m}}{ }^{\prime}$ \\
\hline \multicolumn{9}{|l|}{ Irrigation } \\
\hline $40 \%$ (normal) & 427.10 & 2112.72 & 1658.60 & 0.8058 & 0.600 & 0.7833 & 0.238 & 1789 \\
\hline $70 \%$ (stress) & 429.00 & 1865.70 & 1436.60 & 0.6952 & 0.605 & 0.7944 & 0.238 & 1917 \\
\hline \multicolumn{9}{|c|}{ Methanol (v/v) } \\
\hline 0 (control) & 412.00 & 18666.00 & 1453.00 & 0.7480 & 0.600 & 0.8000 & 0.400 & 1779 \\
\hline $7 \%$ & 383.00 & 2009.00 & 1626.00 & 0.7680 & 0.603 & 0.7600 & 0.130 & 1822 \\
\hline $14 \%$ & 458.80 & 2097.00 & 1628.00 & 0.8048 & 0.616 & 0.8000 & 0.380 & 1908 \\
\hline $21 \%$ & 429.83 & 2193.00 & 1764.00 & 0.8206 & 0.600 & 0.7800 & 0.250 & 1960 \\
\hline $27 \%$ & 426.00 & 1928.00 & 1502.00 & 0.7360 & 0.583 & 0.7800 & 0.260 & 1824 \\
\hline $35 \%$ & 458.00 & 1840.00 & 1382.00 & 0.6240 & 0.580 & 0.8000 & 0.130 & 1827 \\
\hline $\mathrm{LSD}_{0.05}$ & 55.56 & 237.00 & 0.13 & 0.3700 & 24.340 & 0.0410 & 0.250 & 306 \\
\hline
\end{tabular}

Table 5: Simple correlations between chlorophyll fluorescence parameters, chlorophyll content, relative water content and grain yield of soybean plants

\begin{tabular}{|c|c|c|c|c|c|c|c|c|}
\hline & $\mathrm{Chl} . \mathrm{ab}_{2}$ & $\mathrm{Chl}_{\mathrm{ab}}$ & $\mathrm{RWC}_{2}$ & $\mathrm{RWC}_{1}$ & $F_{v}$ & $\mathrm{~F}_{\mathrm{v}} / \mathrm{F}_{\mathrm{m}}$ & $\mathrm{F}_{\mathrm{m}}$ & $\mathrm{F}_{0}$ \\
\hline$\overline{\mathrm{GY}}$ & $0.67 * *$ & $0.62 *$ & $0.77^{\text {*** }}$ & $0.70^{*}$ & $0.06^{\mathrm{ns}}$ & 0.81 ** & $0.96^{* *}$ & $-0.26^{\text {ns }}$ \\
\hline $\mathrm{F}_{0}$ & $-0.65^{\text {ns }}$ & $0.19^{\text {ns }}$ & $-0.06^{\mathrm{ns}}$ & $-0.10^{\text {ns }}$ & $0.33^{\text {ns }}$ & $-0.18^{\mathrm{ns}}$ & $-0.11^{\mathrm{ns}}$ & \\
\hline $\mathrm{F}_{\mathrm{m}}$ & $0.69 * *$ & $0.7 * *$ & $0.80^{\text {ns }}$ & $0.70 * *$ & $0.1^{\text {ns }}$ & $0.8 * *$ & & \\
\hline $\mathrm{F}_{\mathrm{v}} / \mathrm{F}_{\mathrm{m}}$ & $0.38^{\text {ns }}$ & $0.52^{\mathrm{ns}}$ & 0.77 ** & $0.73^{\text {ns }}$ & $-0.14^{\mathrm{ns}}$ & & & \\
\hline$F_{v}$ & $0.41^{\mathrm{ns}}$ & $0.28^{\mathrm{ns}}$ & $0.35^{\mathrm{ns}}$ & $0.25^{\mathrm{ns}}$ & & & & \\
\hline $\mathrm{RWC}_{1}$ & $0.6^{*}$ & $0.63^{*}$ & $0.92 * *$ & & & & & \\
\hline $\mathrm{RWC}_{2}$ & $0.68 *$ & $0.69^{*}$ & & & & & & \\
\hline Chl.ab $_{1}$ & $0.77 * *$ & & & & & & & \\
\hline
\end{tabular}

Methanol applications: Soybean grain yield and chlorophyll concentration and RWC at the second sampling (after the third methanol application) were affected by methanol significantly (Table 1). All applied methanol levels increased grain yield compared to control, except the highest concentration (35\%) that maybe has imposed a toxic effect (Table 2). The highest grain yield was obtained using $21 \%$ methanol, which was significantly $26.1 \%$ greater than control (Table 2).

Methanol application affected $\mathrm{F}_{\mathrm{v}} / \mathrm{F}_{\mathrm{m}}, \mathrm{F}_{\mathrm{v}}$ and $\mathrm{F}_{\mathrm{m}}$ significantly, where as $\mathrm{F}_{0}, \mathrm{QY}, \mathrm{qP}, \mathrm{qN}$ and $\mathrm{F}_{\mathrm{m}}$ ' were not influenced by methanol (Table 3 ). $\mathrm{F}_{\mathrm{m}}$ and $\mathrm{F}_{\mathrm{v}}$ values and their ratio were increased with increasing amount of methanol foliar application up to $21 \%(\mathrm{v} / \mathrm{v})$, with a declining trend onward (Table 4).

Chlorophyll content did not respond to methanol before the third application; however, when measured after the third application, chlorophyll content showed significant difference between different levels of methanol (Table 3 and 4). Similar to fluorescence parameters, the highest chlorophyll concentration was also observed at $21 \%$ (v/v) methanol, with values at 28 and $35 \%$ methanol concentrations lower than control (no-methanol, Table 4).

\section{DISCUSSION}

Effects of soil moisture: Delayed irrigating until $70 \%$ of soil moisture was depleted caused plants to produce lower yields (Table 2), as a result of less received water. It seems that soybean grain yield is most affected by water stress ${ }^{[26,35]}$, probably due to a reduction of seeds per pod as a consequence of blossom drop at flowering $^{[35]}$ (Table 1).

Reduced chlorophyll concentrations in response to drought (Table 2) also found in $\operatorname{corn}^{[13]}$ and in bread $^{[24,25]}$ and durum ${ }^{[3]}$ wheat; however Ommen and Donnelly ${ }^{[23]}$ observed increased chlorophyll content of spring wheat flag leaves at flowering stage under drought stress compared to non-stress condition. It seems, in general, that chlorophyll concentration would be reduced certainly under severe and extended water stress, as also have been reported by Ahmadi and Ceiocemardeh $^{[1]}$ in different wheat cultivars and climatic conditions, but it is possible to increase in moderate stress, showing dependency of chlorophyll concentration response to environmental conditions and genotype $^{[5]}$. Increased chlorophyll by moderate stress maybe is a result of increased specific leaf area and reduced leaf area ${ }^{[32]}$, due to reducing new cells size. As 
a consequence, leaf chlorophyll content increase upon exposure to moderate stress because of larger cells per a leaf weight basis $^{[17]}$.

The more suitable genotypes for arid areas are those can maintain more water content and have a higher RWC without closing their stomata ${ }^{[26]}$, due to positive effects of higher RWC on more stomata opening and $\mathrm{CO}_{2}$ fixation and thereby leaves photosynthesis capacity ${ }^{[26]}$. On the other hand, however, RWC reduction and stomata closing are among the first drought impacts on plants, which may reduce crop yield through disturbing photosynthesis processes ${ }^{[12]}$. Our results also showed a lower RWC in drought condition (70\% SMD) and difference with normal (40\% SMD) condition was more obvious in later sampling. Therefore, RWC can be used as a valuable, sensitive index for screening under drought stress.

Except for initial Fluorescence $\left(\mathrm{F}_{0}\right)$ photochemical capacity of PSII $\left(\mathrm{F}_{\mathrm{v}} / \mathrm{F}_{\mathrm{m}}\right)$, variable $\left(\mathrm{F}_{\mathrm{v}}\right)$ and maximum $\left(\mathrm{F}_{\mathrm{m}}\right)$ fluorescence were lower in plants irrigated at $70 \% \mathrm{SMD}$, in agreement with Araus et al. ${ }^{[3]}$ and Liang et $a l^{[16]}$, which reflect destruction of reaction center of PSII under drought stress condition. Havaux and Lannoye ${ }^{[10]}$ believed that drought stress may not cause significant changes in $\mathrm{F}_{0}$ per se, but in combination with heat stress can lead to PSII reaction center destruction. Generally, chlorophyll fluorescence is high when the first electron receptor (queinon, Q) is in its reduced state, showing higher $F_{v}$ in this situation. In the other hand, a higher $F_{v}$ indicates full reduction of electron receptor $(\mathrm{Q})^{[14]}$. But, $\mathrm{Q}$ would be oxidized under stress, inducing lowered Chla fluorescence and then reduced $F_{v}$. Environmental stresses may reduce $F_{v}$ by inhibition of PSII photo-oxidation. It can be concluded, therefore, that drought stress probably disrupt electron transfer process at $\mathrm{H}_{2} \mathrm{O}$ break-down reaction in PSII, with negligible effects on electron flow after the first electron receptor $(\mathrm{Q})$, which reduce quantum efficiency of net photosynthesis ${ }^{[14,24,25]}$.

The value of $\mathrm{Fv} / \mathrm{Fm}$ parameter reflect PS II capacity for electron transport ${ }^{[9,24,25]}$, thus this declined $F_{v}$ to $F_{m}$ ratio reflect a reduction in photo-protection level and also indicate drought stress has affected photosynthesis efficiency significantly. Concerning relatively constant $\mathrm{F}_{0}$ among irrigation levels, $\mathrm{F}_{\mathrm{m}}$ can be accounted for most of reduction in $\mathrm{F}_{\mathrm{v}} / \mathrm{F}_{\mathrm{m}}$. Plant cannot utilize substrate and energy optimally under stress condition, due to a disruption in electron transfer pathway and destruction of photosynthesizing tissues, leading to a drastic reduction of substrate and energy use efficiency in these conditions ${ }^{[20]}$, as may be a reason for dropped grain yield in stress treatment of our experiment (Table 2), as has been also observed in wheat ${ }^{[24,25]}$. Thus, it may be concluded that $F_{v} / F_{m}$ reduction is mostly a consequent of chlorophyll dysfunction, confirmed by reduced chlorophyll content in the second sampling (Table 2) and can be used as a measure to determine photosystems efficiency.

Methanol applications: In general, methanol application improved crop yield, and the moderate methanol applications (14-21\% v/v) were more effective in this respect, with some negative impact in the highest concentration (Table 2). In peanut (Arachis hypogaea), also applying methanol increased yield up to $20-30 \%{ }^{[30]}$. The positive effects of methanol on crop yield has also been reported in soybean, with the best result from $25 \%(\mathrm{v} / \mathrm{v})$ concentration ${ }^{[15]}$ and some other crops $^{[22,28,36]}$.

The positive effect of moderate methanol concentration was also observed for $F_{m}$ and $F_{v}$, which amounts of these fluorescence parameters were the lowest at 35\% methanol application (Table 4), again assert negative impact of higher methanol application. It seems higher methanol concentrations can destruct further PS II reaction centers, similar to what that happen under drought, heat and/or light stress ${ }^{[24,25]}$.

These results indicate moderate foliar applications of methanol can enhance chlorophyll and photosynthetic capacity for dry matter production, but higher methanol concentration can destroy chlorophyll content. An increased SPAD value in moderate methanol applications (10-30 volumetric percent) and negative impacts of higher doses also has been reported for peanut $^{[30]}$. Theodoridou et al. ${ }^{[33]}$ observed an increased interior contents of cells and also a higher $\mathrm{Chl} \mathrm{a} / \mathrm{b}$ ratio in microalgaes following methanol application. Ramberg et al. ${ }^{[28]}$ and Ramirez et al. ${ }^{[29]}$ stated that spraying methanol on water-deficit pants can increase chlorophyll content of their leaves, when treating wellwatered plants with methanol may slightly reduce their chlorophyll. In our study, there were positive correlations between leaf chlorophyll content and RWC and also grain yield (Table 5). Makhdum et al. ${ }^{[17]}$ also have reported higher leaf turgor when cotton plants were treated with $15 \%(\mathrm{v} / \mathrm{v})$ of methanol, suggesting that methanol can improve water status of leaves and thereby, enable them to maintain their chlorophyll. The change of RWC at the second sampling in response to increasing methanol concentrations was similar to chlorophyll content (Table 2). Other findings ${ }^{[29,30,36]}$ have also emphasized on increasing cell relative water content upon methanol application, which may be a possible reason for higher observed yields with methanol application. 
There were high, positive correlations between grain yield and $\mathrm{F}_{\mathrm{m}}$ and $\mathrm{F}_{\mathrm{v}} / \mathrm{F}_{\mathrm{m}}$ parameters and also with RWC and chlorophyll contents at both samplings (Table 5). In contrast, Araus et al. ${ }^{[3]}$ also reported a high, positive correlation between grain yield and $F_{v}$, with the lowest correlation with $\mathrm{F}_{\mathrm{v}} / \mathrm{F}_{\mathrm{m}}(\mathrm{r}=0.34)$ in durum wheat. Nevertheless in bread wheat, Paknejad et al. ${ }^{[24,25]}$ found the highest correlations of grain yield with $\mathrm{F}_{\mathrm{m}}, \mathrm{F}_{\mathrm{v}}$ and $\mathrm{F}_{\mathrm{v}} / \mathrm{F}_{\mathrm{m}}$ parameters. These inconsistent findings may be partly associated with nature of treatments and environmental conditions.

\section{CONCLUSION}

Under water stress condition, closing of stomata and probably higher transpiration led to lower leaves water content. Indeed destruction of chlorophyll and a disturbance in electron transfer pathway which led to lower photosynthesis capacity caused grain yield to be declined. Furthermore, it seems applying methanol on water stressed soybean plants can reduce, at least partly, negative impacts of drought and improve plant potential to withstand prevailing harsh and dry climate in arid areas.

\section{REFERENCES}

1. Ahmadi, A. and A. Ceiocemardeh, 2004. Effect of drought stress on soluble carbohydrate, chlorophyll and Proline in four adopted wheat cultivars with various climates of Iran. Iranian J. Agric. Sci., 35: 753-763.

2. Andres, A.R, J.J. Lazaro, A. Chueca, R. Hermoso and J.L. Gorge, 1989. Effect of alcohols on the association of photosynthetic fructose-1,6bisphosphatase to thylakoid membranes. Physiol. Plantarum, 78: 409-413. DOI: 10.1111/j.13993054.1990.tb09056.x

3. Araus, J.L., T. Amaro, J. Voltas, H. Nakkoul and M.M. Nachit, 1998. Chlorophyll fluorescence as a selection criterion for grain yield in durum wheat under Mediterranean conditions. Field Crops Res., 55: 209-223. DOI: 10.1016/S0378-4290(97)00079-8

4. Behra, R.K., P.C. Mishra and N.K. Choudhury, 2002. High irradiance and water stress induce alterations in pigment composition and chloroplast activities of primary wheat leaves. J. Plant Physiol., 159: 967-973. DOI: 10.1078/0176-1617-00823

5. Boyer, J.S., P.A. Armand and R.E. Sharp, 1987. Light Stress and Leaf Water Relations. In: Photoinbibition. Amsterdam, Kyle, D.J., C.B. Osmoud and C.J. Arntzen (Eds.). EIsevier Science Publishers BV., ISBN: 10: 0444808906, pp: 111-122.
6. Castrillo, M. and I. Trujillo, 1994. Ribulose-1-5, biphosphate carboxylase activity and chlorophyll and protein content in two cultivars of French bean plants under water stress and rewatering. Photosynthetica, 30: 175-181.

7. Fall, R. and A.A. Benson, 1996. Leaf methanolthe simplest natural product from plants. Trends Plant Sci., 1: 296-301. DOI: 10.1016/S13601385(96)88175-0

8. Galbally, E. and W. Kirstine, 2002. The production of methanol by flowering plants and the global cycle of methanol. J. Atmos. Chem., 43: 195-229. DOI: 10.1023/A:1020684815474

9. Graan, T. and J.S. Boyer, 1990. Very high $\mathrm{CO}_{2}$ partially restores photosynthesis in sunflower at low water potentials. Planta, 181: 378-384. DOI : 10.1007/BF00195891

10. Havaux, M., M. Emez and R. Lannoye, 1998. Screening of varieties of durum wheat (Triticum durum Desf.) and bread wheat (Triticum aestivum L.) for drought adaptation by measuring in vivo chlorophyll f luorescence quenching. Agronomie, 8: 193-199.

http://www.agronomy-journal.org/articles/agro/ pdf/1988/03/Agronomie_0249

11. Hemming, D. and R. Criddle, 1995. Effects of methanol on plant respiration. J. Plant Physiol., 146: 193-198.

http://www.springerlink.com/content/x0314403205 55706/

12. Jabari, F., K. Postini and A. Ahmadi, 2006. Effect of relation activity enzymes antioxidant on chlorophyll content and cell membrane stability of wheat cultivars. Iranian J. Agric. Sci., 37: 307-316.

13. Jun, C. and D. Junying, 1996. Effect of drought on photosynthesis and grain yield of corn hybrids with different drought tolerance. Acta Agronomica Sinica, 22: 757-762. http://211.155.251.148:8080/zwxb/EN/article/dow nloadArticleFile.do? attachType $=$ PDF\&id $=1002$

14. Lambers, H., F. Stuart Chapin III and T.L Pons, 2008. Plant Physiological Ecology. 2nd Edn., Springer Science, Business Media, LLC., New York, USA., ISBN: 10: 0387983260, pp: 604.

15. Li, Y., J. Gupta and A.K. Siyumbano, 1995. Effect of methanol on soybean photosynthesis and chlorophyll. J. Plant Nutr., 18: 1875-1880. http://cat.inist.fr/?aModele $=$ afficheN\&cpsidt $=3625188$

16. Liang, J., J. Zhang and M. Woog, 1997. Can stomatal closure caused by xylem ABA explain the inhibition of leaf photosynthesis under soil drying? Photosynthesis Res., 51: 149-159. DOI: 10.1023/A:1005797410190 
17. Makhdum, M.I., M.N.A. Malik, S.U. Din, F. Ahmad and F.I. Chaudhry, 2002. Physilogical response of cotton to methanol foliar application. J. Res. Sci., 13: 37-43.

http://www.springerlink.com/content/g7635q7n170 r5410/

18. Masojidek, J., S. Trivedi, L. Halsbaw, A. Alexiou and D.O. Hall, 1991. The synergistic effect of drought and light stresses in sorghum and pearl millet. Plant Physiol., 96: 198-207. http://www.plantphysiol.org/cgi/content/abstract/9 $6 / 1 / 198$

19. Matin, M.A., J.H. Brown and H. Ferguson, 1989. Leaf water potential, relative water content and diffusive resistance as screening techniques for drought resistance in barley. Agron. J., 81: 100-105.

http://agron.scijournals.org/cgi/content/abstract/81/ $1 / 100$

20. Méthy, M., A. Olioso and L. Trabaud, 1994. Chlorophyll fluorescence as a tool for management of plant resources. Remote Sens. Environ., 47: 2-9. DOI: 10.1016/0034-4257(94)90121-X

21. Moffatt, J.M., R.G. Sears and G.M. Paujsen, 1990. Wheat high temperature tolerance during reproductive growth: I. Evaluation by chlorophyll fluorescence. Crop Sci., 30: 881-885. http://crop.scijournals.org/cgi/content/abstract/30/4 /881

22. Nonomura, A.M. and A.A. Beson, 1992. The path to carbon in photosynthesis: Improved crop yields with methanol. Proc. Natl. Acad. Sci. USA., 89: 9794-9798. PMID: 1409701

23. Ommen, O.E., A. Donnelly, S. Vanhoutvin, M. van Oijen, and R. Manderscheid, 1999. Chlorophyll content of spring wheat flag leaves grown under elevated $\mathrm{CO}_{2}$ concentrations and other environmental stresses within the 'ESPACE-wheat' project. Eur. J. Agron., 10: 197-203. DOI: 10.1016/S1161-0301(99)00011-8

24. Paknejad, F., E. Majidi, G. Normohamadi, A. Seadat and S. Vazan, 2007. Evaluation of drought stress on effective traits at accumulative assimilate of grain in different cultivars of wheat. Iranian J. Agron. Sci., 1: 137-149.

25. Paknejad, F., M. Nasri, H.R. Tohidi Moghadam, H. Zahedi and M. Jami Alahmad, 2007. Effects of drought stress on chlorophyll fluorescence parameters, chlorophyll content and grain yield of wheat cultivars. J. Biol. Sci., 7:841-847. http://scialert.net/pdfs/jbs/2007/841-847.pdf 26
26. Por Mousavi, M., M. Galavi, J. Danshiyan, A. Ghanbari and N. Basirani, 2007. Effects of drought stress and manure on leaf relative water content, cell membrane stability and leaf chlorophyll content in soybean (Glycine max). J. Agric. Sci. Nat. Resour., 60: 125-134.

27. Rajala, A., J. Karkkainen, J. Peltonen and P. Peltonen-Sainio, 1998. Foliar application of alcohols failed to enhance growth and yield of $\mathrm{C}_{3}$ crops. Ind. Crop Prod., 7: 129-137. DOI: 10.1016/S0926-6690(97)00041-1

28. Ramberg, H.A., J.S.C. Bradley, J.S.C. Olson, J.N. Nishio, J. Markwell and J.C. Osterman, 2002. The role of methanol in promoting plant growth: An update. Rev. Plant Biochem. Biotechnol., 1: 113-126.

http://www.springerlink.com/content/e6k1q754753 $1145 \mathrm{u} /$

29. Ramirez, I., F. Dorta, V. Espinoza, E. Jimenez, A. Mercado and H. Pen a-Cortes, 2006. Effects of foliar and root applications of methanol on the growth of Arabidopsis, tobacco and tomato plants. J. Plant Growth Regul., 25: 30-44. DOI: 10.1007/s00344-005-0027-9

30. Safarzade Vishgahi, M.N., G.H. Normohamadi, E. Majidi Haravan and B. Rabiei, 2005. Effect of methanol on peanut Growth and yield (Arachis hypogaea L.). Iranian J. Agric. Sci., 1: 88-103.

31. Shibairo, S.I., M.K. Opadhyaya and P.M.A. Toivonen, 1998. Influence of preharvest water stress on postharvest moisture loss of carrots (Daucus carota L.). J. Hort. Sci. Biotech., 73: 347-352.

http://www.springerlink.com/content/g7635q7n170r5410

32. Taiz, L. and E. Zeiger, 2006. Plant Physiology. 3rd Ed., Sinauer Associates, Sunderland, MA., ISBN: 13: $9780878938568, \mathrm{pp}: 705$.

33. Theodoridou, A., D. Dornemann and K. Kotzabasis, 2002. Light-dependent induction of strongly increased microalgal growth by methanol. Biochim. Biophys. Acta, 1573: 189-198. 189-198. http://cat.inist.fr/?aModele $=$ afficheN\&cpsidt $=1397$ 6669

34. Zarea, M., J. Daneshian and H. Zeynali Khaneghah, 2004. Variability for drought resistance in soybean. Sci. J. Agric. Iranian, 27: 33-50.

35. Zbiec, I., S. Karczmarczyk and C. Podsiado, 2003. Response of some cultivated plants to methanol as compared to supplemental irrigation. Elec. J. Polish Agric. Univ. Agron., 6: 1-7. .http://www.ejpau.media.pl/volume6/issue1/agrono my/art-01.html 